\title{
DEVELOPMENT OF NOVEL CELLULOSE-BASED FUNCTIONAL MATERIALS*
}

Mirjana Kostić**

Faculty of Technology and Metallurgy, University of Belgrade, Belgrade, Serbia
(REVIEW PAPER)

UDC 677.46:66.017

DOI 10.5937/savteh2102073K
Nowadays, functional materials based on renewable bioresources and environmentally friendly processes have attracted increased attention of both the industrial and the scientific community. Cellulose, the structural material of all plants, is the most abundant natural and renewable polymer possessing some promising properties, such as mechanical robustness, hydrophilicity, biocompatibility, and biodegradability. This paper gives an overview of the current cellulose research directed towards an advanced understanding and application of this most important bioresource. Emphasis is placed on cellulose functionalization and its conversion into novel high-performance cellulose materials with tailored properties (such as fibers, films, membranes, composites, and biomedical materials). Various physical and chemical treatments (alkalis, oxidizing agents, acetylation, ultrasound treatment, plasma treatment, and many other single or combined methods) used for cellulose modification to adjust its properties for different purposes, have been concisely reviewed. Furthermore, the unique hierarchical architecture of natural cellulose consisting of nanoscale fibrils and crystallites allows the extraction of the nanocrystals, and micro- and nanofibrilated cellulose via mechanical and chemical methods or their combination. These nanocellulose materials offer great opportunities in the field of advanced and functional materials. Finally, a novel platform to prepare various cellulose-based materials through more efficient and environmentally friendly processes based on recently developed new and "green" solvents for cellulose has also been discussed.
Keywords: cellulose-based functional materials, cellulose functionalization, nanofibrillated cellulose, properties, application

\section{Introduction}

Renewable resources, which were important for the production of commodities and many technical products before the Industrial Revolution, are gaining more and more interest in our modern society due to their positive effects on agriculture, the environment, and the economy. Nowadays, functional materials based on renewable bioresources and environmentally friendly processes have attracted increased attention from both the industrial and scientific communities. Cellulose, the structural material of all plants, which accounts for approximately 40 percent of plant biomass, is the most abundant natural and renewable polymer possessing some promising properties, such as mechanical robustness (high specific strength, flexibility during processing, high specific stiffness, etc.), hydrophilicity, biocompatibility, and biodegradability. Conventional sources of cellulose include cotton and wood, which are discouraged today on account of the cost of the former and environmental regulations associated with the latter.
In this regard, cellulose-rich biomass derived from nonconventional sources such as flax, hemp, jute, ramie, etc., annual plants that cause little or no detrimental effect on the ecosystem and can grow in different climatic zones, acquires enormous significance [1-7].

The resources of cellulose fibers available in the plant world, with annual production estimated to be over $7.5 \times 10^{10}$ tons [8], are virtually inexhaustible, but only a small portion of these resources has been used as raw material for textile, paper and other industries. Wood pulp is still the most important raw material source for the processing of cellulose, most of which is used for the production of paper and cardboard. In spite of the impact of the booming Internet and paperless reading, the role of paper remains important with the global production of paper and cardboard amounted to about 420 million metric tons in 2018, Table 1. Although there was a slight decrease in 2009 , the production of paper and cardboard worldwide has been steadily ris\footnotetext{
as a plenary lecture, Faculty of Technology in Leskovac, 22-23 October, 2021.

**Author address: Mirjana Kostić, Faculty of Technology and Metallurgy, University of Belgrad,

Karnegijeva 4, 11000 Belgrade, Serbia

E-mail: e-mail: kostic@tmf.bg.ac.rs

The manuscript received: 20. 10. 2021.

Paper accepted: 20. 10. 2021.
}

*The paper was presented at 14th Symposium with international participation "NOVEL TECHNOLOGIES AND ECONOMIC DEVELOPMENT", 
ing in recent years, Table 1. Further increase of worldwide paper production is projected in the coming decades, approaching 450 million metric tons before 2030 . Whilst demand for graphic paper (i.e. printing, writing, and newspaper) is decreasing globally, packaging paper and board have been growing in demand in recent years due to the rapid expansion of the online selling business model.

Table 1. Production volume of paper and cardboard worldwide 2008-2016 (in thousand metric tons)

\begin{tabular}{lcccc}
\hline Year & Packaging paper and board & Graphic paper & Other & Total \\
\hline 2008 & 193,501 & 151,4894 & 5,922 & 390,912 \\
2009 & 190,208 & 136,3854 & 4,094 & 370,687 \\
2010 & 204,469 & 142,8664 & 6,564 & 393,899 \\
2011 & 209,982 & 142,0474 & 6,946 & 398,975 \\
2012 & 213,955 & 138,7654 & 7,275 & 399,995 \\
2013 & 219,455 & 134,6004 & 8,550 & 402,605 \\
2014 & 225,624 & 131,078 & 49,789 & 406,491 \\
2015 & 231,022 & 125,5015 & 1,072 & 407,595 \\
2016 & 235,544 & 122,6245 & 2,715 & 410,883 \\
2017 & 245,782 & 119,678 & 54,227 & 419,687 \\
2018 & 256,128 & 115,571 & 48,011 & 419,710 \\
\hline Source: @) Statista $2021[9]$ & & &
\end{tabular}

Man-made cellulosic fibers (MMCF) such as Viscose/Rayon, Lyocell, Modal and Cupro, form the second biggest cellulosic fiber group after cotton. With an annual production of around 7.1 million tons in 2019, the global production of MMCF has been more than doubled since 1990. Viscose is the dominant MMCF with a production volume of around 5.63 million tons in 2019 , followed by acetate with a production volume of around 0.95 million tons in 2019 , but it is largely utilized for non-textile applications. Lyocell ranks third most utilized MMCF with a production volume of 0.3 million tons and strong potential to grow faster than the others MMCF. Modal fibers rank fourth with a production of around 0.2 million tons, while in the case of Cupro fiber, there is only one provider manufacturing 17,000 tons in 2019 [10].

In spite of the production growth, the sector has faced considerable social and environmental challenges, such as deforestation and biodiversity impacts related to raw material sourcing, safe chemical use, and labor rights concerns in the production process [11]. At the same time, with enhanced sector sustainability standards, an MMCF made from wood pulp and natural plant materials could hold the key for developing truly circular fashion industry. This issue is very important considering that by 2025, the need for clothes will double, and the demand for fibers that provide comfort will approach 40 million tons per year until 2050, while cotton production is expected to reach 28 million. tons/ year [12].

The applications of cellulosic materials can be extended far beyond the mentioned traditional applications areas. Regarding new directions in cellulose re- search and advanced understanding and application of this most important bioresource, the following topics should be addressed:

- $\quad$ (advanced) analytical characterization [13,14];

- new routes of modification (modification under homogeneous (acylation, sulfation, nucleophilic displacement reactions, amino celluloses, etc.) and heterogeneous conditions) [4,15-19];

- $\quad$ the search for entirely new products and uses (added-value materials from wood pulp and cellulose fibers: functional fibers, cellulose-based nanomaterials, cellulose beads, cellulose-based composites) [5,8,20-32];

- $\quad$ questions of mass production (in most cases the novel materials are very specialized products with great added-value but low demand) $[26,27,30]$.

This paper gives an overview of the current cellulose research directed towards an advanced understanding and application of this most important bioresource. Emphasis is placed on cellulose functionalization and its conversion into novel high-performance cellulose materials with tailored properties (such as fibers, films, membranes, composites, and biomedical materials).

\section{Cellulose functionaliazation}

Cellulose has the same molecular structure, independently on the source; it is a linear syndiotactic homopolymer with repeating anhydro-D-glucose units (AGUs) in a chair conformation, which are linked by $\beta$ - $(1 \rightarrow 4)$-glycosidic bonds, Fig. 1 . However, the chain length of cellulose expressed in the number of constituent AGUs (degree of polymerization, DP) depends on the origin and cellulose extraction method. 
Cotton and other plant fibers, as well as bacterial cellulose, have DP values in the 800-10000 range, depending on the treatment. In the wood pulp, the values are typically between 300 and 1700 repeating units per chain, while man-made cellulose fibers contain 250500 AGUs per chain. There are three hydroxyl groups present at each AGU: one primary hydroxyl group at C6 and two secondary hydroxyl groups at C2 and C3. Furthermore, the cellulose chain consists at one end of AGU with a secondary hydroxyl group at C4 (the nonreducing end); while the other end is terminated with the C1 hydroxyl group, which is in equilibrium with the aldehyde structure (the reducing end). As a result of a large number of hydroxyl groups along the skeleton, the extended network of hydrogen bonds (intra- and inter-molecular bonds) are formed giving cellulose a multitude of partially crystalline fiber structures and morphologies. The properties of cellulose are therefore determined by a defined hierarchical order in supramolecular structure and organization. [15,24,30].

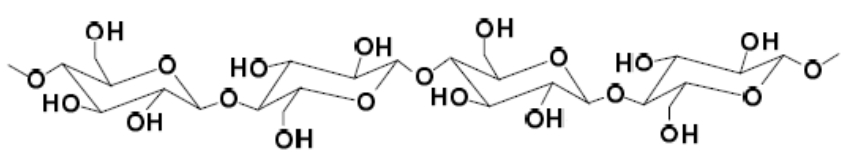

Figure 1 The molecular structure of cellulose

Increased interest of various industrial sectors in the use of in the use of the cellulose and cellulose fibers has resulted in the development of new or improvement of existing processes for their modification to homogenize their structure and properties, clean the surface of fibers, reduce non-cellulosic substances, increase the degree of elementalization and surface roughness, improve mechanical properties, modify sorption properties (increase/decrease of hydrophilicity), or tailor cellulose structure and properties for different purposes. Cellulose unique structure combined with reactive groups (3 hydroxyl functions of different reactivity) allows the design of structures and hence of properties of this fascinating biomaterial [15,16,18,30,33,34].

Functional cellulose materials, which possess particular functionalities while preserving their excellent mechanical properties, can be obtained by different chemical, enzymatic, or physical treatments of the surface (hydrophobization and oleophobization, different noncovalent interaction, selective oxidation, grafting), indepth (the formation of a sleeve of numerous macromolecular layers) or bulk modification of cellulose substrate $[15,35,36]$.

Physical treatments alter the structural and surface properties of the cellulosic materials and according to the achieved effects they are divided on the treatments promoting separation of fiber bundles into more homogenous structures - elementary fibers, such as stretching, calendaring, steam explosion, thermomechanical, and ultrasound treatments; and treatments for fiber sur- face modification, such as corona, dielectric barrier and plasma discharges, and more recently laser and UV irradiation. Plasma-based treatments (corona, low- and atmospheric pressure plasma) deserve special attention due to some unique properties and growing demands on the environmental friendliness of processes for surface modification and coating of textiles $[16,17,36]$.

Cellulose has poor reactivity and limited potential for surface engineering with advanced chemical functionalization in water. Chemical modification is the most important path to adapt the properties to the application in question and even to develop novel functional polymers based on cellulose, with advances in performance and application, especially products with a controlled preset functionalization pattern, the so-called "biopolymers for the future". Thanks to the three hydroxyl groups per anhydroglucose unit, cellulose can be easily functionalized by chemical modification since these groups may be involved in different reactions common to all primary and secondary alcohols such as esterification and etherifications, oxidation, acetylation, chemical coupling. Chemical modifications may activate hydroxyl groups or introduce new moieties that can be either used directly because of their special properties, such as hydrophobization, hydrophilization or even water solubility, or they can be used as reactive "chemical hooks" for further modification [15,30,36].

Esters and ethers were pioneer compounds of cellulose chemistry, and remain the most important cellulose derivatives from the perspective of application, such as fibers, films, plastics, coatings and filtration media, as well as additives for food products, cosmetics, pharmaceuticals, the extractive industry and so on. Cellulose esters have been known for almost two centuries, with important commercial applications for nearly a century. They are commonly derived from natural cellulose by reaction with organic acid chlorides or anhydrides, as acylation reagents, performed in heterogeneous or quasi-homogeneous media. Cellulose esters of almost any organic acid can be prepared; however, esters of acids containing more than four carbon atoms have not achieved commercial significance. Cellulose acetate (CA) and triacetate (CTA) are the most important organic ester of cellulose due to their applications, the former one in fibers (cigarette filters and textile fibers), plastics (the original Lego bricks), films, separation membranes, and coatings, and the latter as fibers and films (for example, as: polarizer films for LCD screens; specialized overhead projector transparencies; specialized photographic film; motion picture film, production of animation celluloids; packaging). Inorganic esters of cellulose have also been obtained by classical heterogeneous procedures. Among inorganic cellulose esters, a few esters should be pointed out: cellulose nitrate, the oldest cellulose derivative and the commercially most important inorganic ester of cellulose whose applications includes plastics, lacquers, coatings, explosives and propellants; cellulose borate possessing a cation-exchange capacity 
and enhanced thermal stability; cellulose sulfates with commercially promising applications related to their filmforming properties, special rheological effects, behavior as an anionic polyelectrolyte, and biological activity (suitable for encapsulation of living cells, blood anticoagulant, etc.); phosphorus-containing cellulose derivatives whose applications include the preparation of cellulosebased cation exchangers and the flame proofing of cellulosic textiles [24,37-39].

Cellulose ethers, such as carboxymethylcellulose (CMC), methylcellulose (MC), hydroxyethylcellulose (HEC), hydroxypropylcellulose (HPC), hydroxyethylmethylcellulose (HEMC), and hydroxypropylmethylcellulose (HPMC), are widely used as additives in various food products (e.g. ice cream, beverages, different milk products), cosmetics, pharmaceuticals (e.g. tablet coatings), detergents, oil drilling fluids, dispersion paints, wallpaper paste, and tile adhesive, acting as thickeners, water retention agents, suspending aids, protecting colloids, film formers or thermoplastics. The most common cellulose ethers are carboxymethylcellulose, methylcellulose and ethylcellulose [39].

Among numerous chemical reactions for cellulose modification, cellulose oxidation is quite frequently used to impart special properties to cellulosic fibers. Cellulose, with its polyhydric alcohol structure, is very sensitive to oxidizing media. Cellulose oxidation is rather complex since the three hydroxyl groups of AGU have different reactivities, different regions of the cellulosic material have different accessibilities, and different oxidants behave in different ways, making it difficult to produce materials that have homogeneous chemical and physical properties. Extensive modifications, which accompany cellulose oxidation, give rise to products whose chemical and physical properties depend upon the oxidizing reagent used and the acidity or alkalinity of the medium in which oxidation occurs. The chemical structure of cellulose is altered in a way that hydroxyl groups are oxidized into the corresponding carbonyl structure, i.e. an aldehyde at C-6 and a ketone at C-2 and C-3, or carboxyl moiety (at C-6). Oxidation can also be accompanied by a change in the carbon skeleton of the cellulose backbone, for instance, a carbon-carbon bond cleavage between $\mathrm{C}-2$ and $\mathrm{C}-3$ allows the introduction of aldehyde or carboxyl structures also at C-2 and C-3, which would not otherwise be possible. Cellulose degradation (chain cleavage) often accompanies oxidation, but is actually caused by subsequent reactions and not by oxidation itself. Oxidation as one of the very few processes that render cellulose bioabsorbable in humans gives rise to products whose chemical and physical properties depend upon the oxidizing reagent used, resulting in selective or non-selective oxidation patterns [36,40-43].

There are two common procedures frequently applied for selective oxidation of cellulose: the 2,2',6,6'-tetramethylpiperidine-1-oxyl (TEMPO) mediated oxidation and the periodate oxidation. Oxidative conversion of glucans by the system TEMPO / sodium hypochlorite / po- tassium bromide was first reported in 1994 [44,45] and has been widely investigated since then with Isogai's group being at the forefront of this research area and developing an optimized technique to treat wood and other lignocellulosic fibers under mild basic conditions to facilitate their progressive unraveling as a consequence of the electrostatic repulsion generated by the formation of carboxylic groups and obtaining individual microfibers in a couple of hours at room temperature $[40,46]$.

The reaction causes selective oxidation at $\mathrm{C} 6$ of the AGU to carboxylic groups via the intermediate aldehyde stage, finally producing water-soluble polyglucuronic acids (Figure 2). The nitroxyl radical affects the oxidation from alcohol to the aldehyde oxidation state, while the hypobromide generated in situ from hypochloride and bromide performs further oxidation of the aldehyde to the carboxylic acid. The reaction is usually carried out around $\mathrm{pH}$ 10-11 since at lower $\mathrm{pH}$, hypochlorite becomes an overly aggressive and non-selective oxidant, and TEMPO reactivity is decreased. TEMPO oxidation is usually accompanied by a drastic change of the molecular weight due to $\beta$-elimination starting at the $\mathrm{C} 6$ aldehyde intermediate as the TEMPO-mediated oxidation process is carried out under alkaline conditions [40,47,48].

The amount of cation exchange functions introduced into the cellulose can be tailored by varying the duration of treatment and concentration of oxidizing agents. In the case of TEMPO oxidation of lyocell fibers, applying severe conditions results in loosing fibrous structure and for textile applications only oxidations under mild conditions should be used conditions [48]. In the case of lignocellulosic fibers such as hemp TEMPO oxidation can be used to introduce new functionalities $(0,09$ to $0,80 \mathrm{mmol}$ of carboxylic groups per gramme of fibers), but also to remove lignin and hemicelluloses, as well as improve sorption properties of hemp fibers [49].

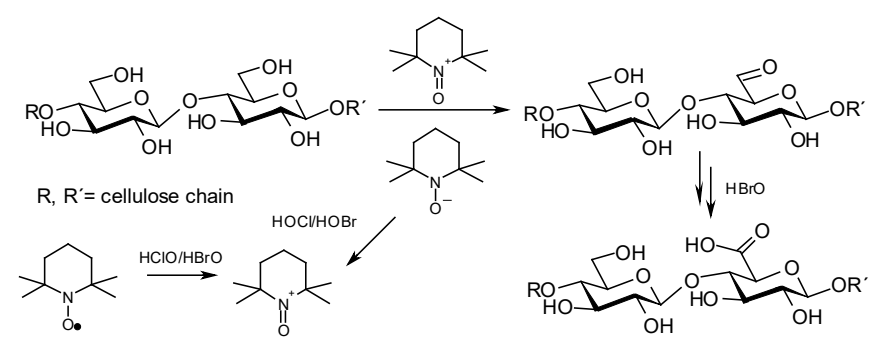

Figure 2 Mechanism of TEMPO oxidation with the intermediate formation of the C6-aldehyde [41]

Periodate oxidation is an attractive and widely used method to modify cellulose due to its highly selective nature (i.e. the reaction proceeds via a cyclic diester of periodic acid with geminal hydroxyls available at $\mathrm{C} 2$ and $\mathrm{C} 3$ of the AGU, which subsequently undergoes an intramolecular redox process with simultaneous $\mathrm{C}-\mathrm{C}$ bond cleavage according to a concerted mechanism [50]), ease of application and only minimal degradation of the starting material.Sodium periodate exclusively oxidizes second- 
Recently, ISO (International Organization for Standardization), TAPPI (the Technical Association of the Pulp and Paper Industry), and CSA (Canadian Standards Association) Standards on CNCs have been developed and published, proposing standard terms and definitions for cellulose nanomaterials based on the nanocellulose size dividing them into two major classes: nanofibers (cellulose nanfibrils, cellulose nanocrystals, and bacterial cellulose), and nanostructured materials (cellulose microcrystals and cellulose microfibrils) [60-62]. The nomenclature, abbreviation, and dimensions applicable to each subgroup are shown in Table 2.

The final features (i.e. morphology, size, and other characteristics) and yield of each nanocellulose class depend on the cellulose origin (diverse wood and nonwood sources including hemp, flax, ramie, jute, sisal, and coir fibers), the isolation and processing conditions, as well as the possible pre- or post-treatments. Wood pulp was the first cellulosic material used to produce nanocellulose and has often been used as the starting material for research on nanocellulose production. However, in the literature there are increasing number of reports dedicated to cellulose nano/microfibril extraction from diverse non-wood sources including hemp [63,64], flax $[63,65]$, ramie $[40]$, jute $[63,66]$, sisal $[63,67,68]$ and coir fibers $[67,69]$. MFC, and more currently NFC, can be viewed as a cellulosic material composed of expanded high-volume cellulose, moderately degraded and greatly expanded in surface area, which, unlike CNC, features both amorphous and crystalline parts and presents a web-like structure $[25,26]$.

Depending upon the source of the cellulose and the method of production, NFC/MFC displays similar morphologies but various dimensions. The dimensions and distribution of dimensions of the fibrillar material are its most important characteristics. Other important properties essential to explain the behavior and the properties of the material are the degree of polymerization (which is strongly correlated with the aspect ratio of the nanofibers and their length), degree of crystallinity, surface chemistry, specific area and toxicity, and the impacts on the environment [24-26,70].

Irrespective of the source, NFC/MFC is manufactured from a pulp/fiber suspension mainly using a mechanical treatment (high-pressure homogenization; microfluidization; grinding; cryocrushing; high-intensity ultrasonication; steam explosion process). Since each of the previously mentioned mechanical treatments requires high energy consumption, the development of disintegration methods that are less energy-consuming becomes a priority in securing the industrialization of NFC/MFC production. Thus, some combinations of pre-treatments and mechanical treatments, such as enzymatic hydrolysis with mechanical shearing and high-pressure homogenization; acid hydrolysis with successive mechanical disintegration, for example, with an ultrasonic homogenizer; TEMPO mediated oxidation pre-treatment usually followed by a mechanical treatment, which can be performed using a cooking blender or an ultra turax system; carboxymethylation and acetylation pre-treatment, etc., improve environmental friendliness and shorten the duration of the nanocellulose production process. Furthermore, combined with pre-treatments and mechanical treatments, a number of post-treatments, such as acetylation, silylation, grafting of coupling agents, are increasingly being carried out in order to enhance the properties of NFC/MFC [10,24-28,40,59,67,70-76].

CNF can also be produced by bottom-up approaches, for example using the electrospinning process, as a rather simple and cost-effective method for the production of nanofibers [27] or wet-type solution blow spinning method [77]. However, both methods require a suitable solvent or chemical derivatization of cellulose. Direct dissolution of cellulose is a difficult process. However, in the last two decades, ionic liquids (ILs) with many attractive properties, including low volatility, high thermal and chemical stability, and structural diversity, have drawn much attention as the promising direct solvents for cellulose [15,78-81], as it will be discussed later.

Cellulose nanocrystals (CNCs) are another important family of cellulosic nanomaterials. They are prepared by an acid hydrolysis process which is intended for dissolving amorphous areas of the cellulose fibers and releasing crystal domains. The obtained nanomaterials, therefore, consist of a sub-entity of cellulose microfibrils having more defined geometrical features and rod-like morphology. The final properties of CNCs depend on the origin of the cellulose, e.g. larger dimensions for CNCs extracted from tunicate and algae sources, as well as from bacterial cellulose, in comparison to CNCs obtained from cotton and wood cellulose, are results of highly crystalline cellulose in these sources, which contains less amorphous regions that leave behind the larger crystalline region. Thitherto, depending on the source of cellulose, different hydrolysis and extraction procedures have been developed. Besides acid hydrolysis, which is the classical way to prepare CNCs, other processes that allow the release of crystalline domains from cellulosic fibers, such as enzymatic hydrolysis and ionic liquid treatment, and hydrolysis with gaseous acid, have been reported $[26,28,29,76]$.

Bacterial cellulose $(\mathrm{BC})$, produced by some bacteria belonging to the genera Acetobacter, Rhizobium, Agrobacterium, Aerobacter, Achromobacter, Azotobacter, Salmonella, Escherichia, and Sarcina, is a naturally derived hydrogel material. Although identical to cellulose of plant origin in terms of molecular formula, BC is quite different in properties due to a very high degree of polymerization (DP values of 2000-8000), crystallinity (values of $60-90 \%$ ), and purity (no association with accompanying substances like hemicelluloses, lignin, or pectin), as well as an extremely high water content ( $90 \%$ or more). BC was originally used as a food source (nata de coco) in Asia, in the form of sweet candies or custards. However, its unique properties have also led to its use as a wound dressing; $\mathrm{BC}$ production for this specific purpose dates 
back to the early 1980s. Its use as a wound-healing material is governed by its outstanding properties, namely: a high water holding capacity, tensile strength, and flexibility; a pronounced permeability to gases and liquids; and great compatibility with living tissues. Furthermore, BC properties essential for wound dressing materials can be tailored by different modifications, especially the inclusion of compounds that can accelerate wound healing $[24,26,32,82,83]$.

In general, the abundant hydroxyl groups on the nanocellulose surface and high surface area to volume ratio make nanocellulose highly reactive and easy to be functionalized via chemical reactions (such as sulfonation, polymer grafting, oxidation, esterification, nucleophilic substitution, etherification, silylation, and carbamation), physical interactions (electric discharge, plasma treatment, ultrasonic treatment, irradiation, and surface fibrillation), and biological approaches (direct and indirect enzyme-mediated modification), leading to the development of various materials with tunable features and desirable properties. Such functionalization can be carried out during the nanocellulose preparation or during the post-production stage [59].

The benefits of the 3-D hierarchical nanostructure of nanocelluloses and their physicochemical characteristics at the nanoscale open new areas of their applications; they can be used as reinforcing components in composites, and MFC/NFC-reinforced foams, in hydro- and aerogels fabrication, as efficient catalysts and electrooptical films, in papermaking applications, microelectronics, gas-barrier films, barrier/separation membranes, cosmetics, flame-resistant materials, pickering emulsifiers, wood adhesives, electroactive polymers, continuous fibers and textiles, food coatings, biomedical applications, and other high-tech and high-performance materials $[10,24-28,33,40,59,66,70,72,84-86]$.

Preparation, morphological features, physical properties and applications of nanocelluloses are comprehensively discussed in following review papers $[8,10,24-$ $26,28,40,59,67,70]$, book chapters [72-75,87] and books [76,88-93]. A variety of market reports and guides for end-users have been published forecasting the nanocellulose market [86,94]. Currently, nanocellulose is produced on an industrial scale in tons per day, with a market forecast to reach USD 783 million by 2025 [59].

Ionic liquids - new ways of cellulose shaping

Despite being known for decades, ionic liquids (ILs), i.e. organic electrolytes with a melting point below $100^{\circ} \mathrm{C}$, emerged as a new class of promising, direct solvents for cellulose only after Swatloski and co-workers [95] from The University of Alabama (USA) reported that cellulose can be dissolved without activation or pretreatment in 1-butyl-3-methylimidazolium chloride ([Bmim] $\mathrm{Cl}$ ) and other hydrophilic ionic liquids, and that it can be regenerated from the solution. Since then, ILs has opened the routes for the use of cellulose as a chemical feedstock for the production of plastics and fibers with enhanced properties. The use of ILs usually comprising imidazolium, pyridinium, or organic ammonium cations and anions such as chloride, bromide, acetate or more complex structures such as hexafluorophosphate, trifluoromethyl sulfonate, etc., as solvents for cellulose, have been investigated either to dissolve or to create appropriate support for the functionalization of cellulose $[10,15,76,78-81]$.

The attractiveness of ILs as solvents comes from their favorable properties such as non-volatility associated with minimal environmental impact, non-flammability, and high thermal stability. Even though a new class of next-generation MMCF named loncell was developed utilizing a novel IL solvent 1,5-diazabicyclo[4.3.0]non5-enium acetate ([DBNH] [OAc]) [96] and has better mechanical properties than all previously known ones (i.e. tensile strength reaching $0.7-0.8 \mathrm{GPa}$ and elastic modulus of $30 \mathrm{GPa}$ [97]), there are some important issues, such as cellulose degradation, side reactions, high viscosities of the solutions (which often require the addition of another molecular solvent) and solvent recovery, that need to be considered further for ILs to reach commercial success. Besides fibers, cellulose solutions in ILs can be shaped as membranes, films, beads, coatings, etc. Currently, nearly a thousand ionic liquids have been described in the literature offering a novel platform for the preparation ofvarious cellulose-based materials through more efficient and environmentally friendly processes based on these new and "green" solvents for cellulose $[10,15,76,78-81]$.

\section{Conclusions}

Cellulose, as the most abundant sustainable resource on the earth, has received more attention in 21st century due to increasingly serious environmental problems, as well as its potential to substitute petrochemicals in all kinds of materials. The cellulose-based functional materials have been developed based on different cellulose types such as NFC, CNCs, BC, CMC, CA, MC, HEC, HPMC, etc. The types of cellulose have played an important role in the properties of cellulose-based functional materials since many distinctive properties inherent in different cellulose types provide a framework which enables the formation of a wide range of advanced materials. Various surface, in-depth, and/or bulk modifications of cellulose offer new opportunities for developing unique functional materials, tuning their structure and properties, and expanding the market for such products, opening totally new application areas. Highly functionalized cellulosic products take advantage of the intrinsic properties of the polymer in combination with modern modifying reagents. However, some challenges should be overcome in order to fully explore the potential applications of such materials both for large-volume products and for highlyadvanced and functional materials in a more sustainable future. In this context, it is essential to intensify the interdisciplinary research and to increase the current 
knowledge in the basic and application-oriented work in the field of cellulose.

\section{Acknowledgment}

This work was supported by the Ministry of Education Science and Technological Development of the Republic of Serbia (Contract No. 451-03-9/2021-14/200135).

\section{References}

[1] L. Fernando, M. P. Duarte, A. Vatsanidou, E. Alexopoulou, Environmental aspects of fiber crops cultivation and use, Industrial Crops and Products, 68 (2015) 105-115.

[2] M. Iman, T. K. Maji, in Lignocellulosic Polymer Composites, V.K. Thakur Ed., Wiley, Hoboken, NJ, 2014, p. 453.

[3] A. J. Jhala, L. M. Hall, Flax (Linum usitatissimum L.): Current uses and future applications, Australian Journal of Basic and Applied Sciences, 4 (2010) 4304-4312.

[4] B. Pejić, M. Vukčević, M. Kostić, in Sustainable Agriculture Reviews 42, G. Crini, E. Lichtfouse (Eds). Springer, Cham, 2020, p. 111

[5] E. Madsen, K. Gamstedt, Wood versus plant fibers: Similarities and differences in composite applications, Advances in Materials Science and Engineering, 2013 (2013) 1-14.

[6] M. Sfiligoj Smole, S. Hribernik, K. Stana Kleinschek, T. Kreže, in Advances in Agrophysical Research, S. Grundas, A. Stepniewski (Eds.), InTech, 2013, DOI: 10.5772/52372. Available from: http://www.intechopen. com/books/advances-in-agrophysical-research/plantfibres-for-textile-and-technical-applications

[7] J. E. G. van Dam, FIBRA WP2 - Biorefinery production chain for fibre crops. Report D2.2: Markets for fibre crops in EU and China, Wageningen UR Food \& Biobased Research, Wageningen, 2014, p.5.

[8] Y.-Y. Li, B. Wang, M.-G. Ma, B. Wang, Review of recent development on preparation, properties, and applications of cellulose-based functional materials, International Journal of Polymer Science, 2018 (2018) Article ID 8973643, https://doi.org/10.1155/2018/8973643

[9] https://www.statista.com/statistics/270317/productionvolume-of-paper-by-type/ (03.10.2021. accessed)

[10] C. Felgueiras, N. G. Azoia, C. Gonçalves, M. Gama, F. Dourado, trends on the cellulose-based textiles: raw materials and technologies, Frontiers in Bioengineering and Biotechnology, 9 (2021) 608826, https://doi. org/10.3389/fbioe.2021.608826

[11] https://www.forumforthefuture.org/man-made-cellulosicfibres (04.10.2021. accessed)

[12] M. Kostić, B. Pejić, J. Milanović, A. Kramar, Cellulose fibers - trends in production and applications (in Serbian) Celulozna vlakna - trendovi u proizvodnji i primeni, Tekstilna industrija, 66(4) (2018) 16-24.

[13] K. Kamide, Cellulose and Cellulose Derivatives, Elsevier Science, 2005

[14] T. Rosenau, A. Potthast, A. Hofinger, M. Bacher, Y. Yoneda, K. Mereiter, F. Nakatsubo, C. Jäger, A. D. French, K. Kajiwara, in Cellulose Science and Technology: Chemistry, Analysis, and Applications, T. Rosenau), A. Potthast, J. Hell (Eds), John Wiley \& Sons, Inc., 2019, p. 99

[15] K. Jedvert, T. Heinze, Cellulose modification and shaping - a review, Journal of Polymer Engineering, 37(9) (2017) 845-860.
[16] M. N. Belgacem, A. Gandini, The surface modification of cellulose fibres for use as reinforcing elements in composite materials, Composite Interfaces, 12 (2005) 4175.

[17] O. Faruk, A. Bledzki, H.-P. Fink, M. Sain, Biocomposites reinforced with natural fibers: 2000-2010. Progress in Polymer Science, 37 (2012) 1552-1596.

[18] J. A. Figueiredo, M. I. Ismael, C. M. S. Anjo, A. P. Duarte, Cellulose and derivatives from wood and fibers as renewable sources of raw-materials, Topics in Current Chemistry, 294 (2010) 117-128.

[19] S. Kalia, B. S. Kaith, I. Kaur, Pretreatments of natural fibers and their application as reinforcing material in polymer composites-A review, Polymer Engineering \& Science, 49 (2009) 1253-1272.

[20] B. Volesky, Biosorption and me, Water Research, 41 (2007) 4017-4029.

[21] A. R. Mohamed, M. Mohammadi, G.N. Darzi, Preparation of carbon molecular sieve from lignocellulosic biomass: A review, Renewable Sustainable Energy Reviews, 14 (2010) 1591-1599.

[22] N. M. Nor, L. L. Chung, L.K. Teong, A. R. Mohamed, Synthesis of activated carbon from lignocellulosic biomass and its applications in air pollution control-a review, Journal of Environmental Chemical Engineering, 1 (2013) 658-666.

[23] M. Kostic, B. Pejic, M. Vukcevic, in: Chemistry of Lignocellulosics: Current Trends, T. Stevanovic (Ed.), Taylor \& Frensis Group/CRC Press, Boca Raton, 2018, p.3.

[24] D. Klemm, F. Kramer, S. Moritz, T. Lindstroem, M. Ankerfors, D. Gray, A. Dorris, Nanocelluloses: A new family of nature-based materials, Angewandte Chemie International Edition, 50 (2011) 5438-5466.

[25] N. Lavoine, I. Desloges, A. Dufresne, J. Bras, Microfibrillated cellulose - Its barrier properties and applications in cellulosic materials: A review. Carbohydrate Polymers, 90 (2012) 735- 764.

[26] D. Klemm, E. D. Cranston, D. Fischer, M. Gama, S. A. Kedzior, D. Kralisch, F. Kramer, T. Kondo, T. Lindström, S. Nietzsche, K. Petzold-Welcke, F. Rauchfuß, Nanocellulose as a natural source for groundbreaking applications in materials science: Today's state, Materials Today, 21(7) (2018) 720-748.

[27] H. Kargarzadeh, M. Mariano, D. Gopakumar, I. Ahmad, S. Thomas, A. Dufresne, J. Huang, N. Lin, Advances in cellulose nanomaterials, Cellulose, 25 (2018) 2151-2189.

[28] P. Panchal, E. Ogunsona, T. Mekonnen, Trends in Advanced Functional Material Applications of Nanocellulose, Processes, 7(1) (2019) 10, doi:10.3390/ pr7010010

[29] K. De France, Z. Zeng, T. Wu, G. Nyström, Functional materials from nanocellulose: Utilizing Structure-Property Relationships in Bottom-Up Fabrication, Advanced Materials, 33 (28) (2020) 2000657, DOI: 10.1002/ adma.202000657

[30] X. Qiu, S. Hu, "Smart" materials based on cellulose: A review of the preparations, properties, and applications, Materials, 6 (2013) 738-781.

[31] M. E. Lamm, K. Li, J. Qian, L. Wang, N. Lavoine, R. Newman, D. J. Gardner, T. Li, L. Hu, A. J. Ragauskas, H. Tekinalp, V. Kunc, S. Ozcan, recent advances in functional materials through cellulose nanofiber templating, Advanced Materials, 33 (2021) 2005538, DOI: 10.1002/ 
adma.202005538,

[32] H. Seddiqi, E. Oliaei, H. Honarkar, J. Jin, L. C. Geonzon, R. G. Bacabac, J. Klein-Nulend, Cellulose and its derivatives: towards biomedical applications, Cellulose, 28 (2021)1893-1931.

[33] S. Kalia, A. Dufresne, B. M. Cherian, B. S. Kaith, L. Avérous, J. Njuguna, E. Nassiopoulos, Cellulose-based bio-and nanocomposites: A review, International Journal of Polymer Science, 2011 (2011) Article ID 837875, doi:10.1155/2011/837875.

[34] S. Kalia, B. S. Kaith, I. Kaur, Cellulose Fibers: Bio- and Nano-Polymer Composites, Springer-Verlag, Berlin, Heidelberg, 2011.

[35] M. N. Belgacem, A. Gandini, Surface modification of cellulose fibres, Polímeros, 15 (2) (2005) https://doi. org/10.1590/S0104-14282005000200010

[36] A. Gandini, M. N. Belgacem, The surface and in-depth modification of cellulose fibers, Advance Polymer Science, 271 (2016) 169-206.

[37] K. J. Edgar, C. M. Buchanan, J. S. Debenham, P. A. Rundquist, B. D. Seiler, M. C. Shelton, D. Tindall, Advances in cellulose ester performance and application. Progress in Polymer Science, 26(9) (2001) 1605-1688.

[38] D. Ciolacu, L. Olaru, D. Suflet, N. Olaru, in: Pulp Production and Processing: From Papermaking to HighTech Products, V. I. Popa (Ed.), Smithers Rapra, 2013, p.253.

[39] J.-L. Wertz, O. Bédué, J. P. Mercier, Cellulose science and technology, EPFL Press, 2010, p. 275.

[40] A. Isogai, T. Saito, H. Fukuzumi, TEMPO-oxidized cellulose nanofibers, Nanoscale, 3 (2011) 71-85

[41] M. Kostić, P. Škundrić, J. Praskalo, B. Pejić, A. Medović, New functionalities in cellulosic fibers developed by chemical modification, Hemijska industrija, 61(5) (2007) 233-237.

[42] A. Potthast, M. Kostic, S. Schiehser, P. Kosma, T. Rosenau, Studies on oxidative modifications of cellulose in the periodate system: Molecular weight distribution and carbonyl group profiles, Holzforschung, 61(6) (2007) 662667.

[43] A. Potthast, S. Schiehser, T. Rosenau, M. Kostic, Oxidative modifications of cellulose in the periodate system Reduction and beta-elimination reactions, Holzforschung, 63(1) (2009) 12-17.

[44] A. E. J. de Nooy, A. C.Besemer, H. van Bekkum, Highly selective tempo mediated oxidation of primary alcohol groups in polysaccharides, Recueil des Travaux Chimiques des Pays-Bas, 113 (1994) 165-166.

[45] A. E. J. de Nooy, A. C.Besemer, H. van Bekkum, Highly selective nitroxyl radical-mediated oxidation of primary alcohol groups in water-soluble glucans, Carbohydrate Research, 269 (1995) 89-98.

[46] A. Isogai, T. Hänninen, S. Fujisawa, T. Saito, Review: Catalytic oxidation of cellulose with nitroxyl radicals under aqueous conditions, Progress in Polymer Science, 86 (2018) 122-148.

[47] J. Milanovic, S. Schiehser, A. Potthast, M. Kostic, Stability of TEMPO-oxidized cotton fibers during natural aging, Carbohydrate Polymers, 230 (2020) 115587

[48] J. Milanovic, S. Schiehser, P. Milanovic, A. Potthast, M. Kostic, Molecular weight distribution and functional group profiles of TEMPO-oxidized lyocell fibers, Carbohydrate Polymers, 98 (2013) 444-450.

[49] J. Milanovic, M. Kostic, P. Milanovic, P. Skundric, Influence of TEMPO-Mediated Oxidation on Properties of Hemp Fibers, Industrial \& Engineering Chemistry Research, 51 (2012) 9750-9759.

[50] A. S. Perlin, Glycol-Cleavage Oxidation, Advances in Carbohydrate Chemistry and Biochemistry, 60 (2006) 183-250.

[51] T. Nikolic, M. Kostic, J. Praskalo, B. Pejic, Z. Petronijevic, P. Skundric, Sodium periodate oxidized cotton yarn as carrier for immobilization of trypsin, Carbohydrate Polymers, 82(3) (2010) 976-981.

[52] T. Nikolic, J. Milanovic, A. Kramar, Z. Petronijevic, Lj. Milenkovic, M. Kostic, Preparation of cellulosic fibers with biological activity by immobilization of trypsin on periodate oxidized viscose fibers, Cellulose, 21(3) (2014) 13691380.

[53] T. Nikolic, Z. Petronijevic, M. Kostic, in: Trypsin: Anatomy, Biological Properties and Applications, D. Faas, J. Holder (Eds), Nova Science Publishers, New York, 2018, p.1.

[54] L. Fras Zemljič, Z. Peršin, O. Šauperl, A. Rudolf, M. Kostić, Medical textiles based on viscose rayon fabrics coated with chitosan-encapsulated iodine: antibacterial and antioxidant properties, Textile Research Journal, 88(22) (2018) 2519-2531.

[55] V. B. Chavan, B. D. Sarwade, A. J. Varma, Morphology of cellulose and oxidised cellulose in powder form, Carbohydrate Polymers, 50 (2002) 41-45.

[56] Z. Sabzalian, M. N. Alam, T. G. M. van de Ven, Hydrophobization and characterization of internally crosslink-reinforced cellulose fibers, Cellulose, 21 (2014) 1381-1393.

[57] J. Song, O. J. Rojas, Approaching super-hydrophobicity from cellulosic materials: A Review, Nordic Pulp \& Paper Research Journal, 28(2) (2013) 216-238.

[58] S. Tanpichai, F. Quero, M. Nogi, H. Yano, R. J. Young T. Lindström, W. W. Sampson, S. J. Eichhorn, Effective Young's modulus of bacterial and microfibrillated cellulose fibrils in fibrous networks. Biomacromolecules, 13 (2012)1340-1349.

[59] D. Trache, A. F. Tarchoun, M. Derradji, T. S. Hamidon, N. Masruchin, N. Brosse, M. H. Hussin, Nanocellulose: From fundamentals to advanced applications, Frontiers in Chemisty, 8 (2020) 392.

[60] ISO/TC 229 - TS 20477:2017 : Standard terms and their definition for cellulose nanomaterial, 2017.

[61] TAPPI. Proposed New TAPPI Standard: Standard Terms and Their Definition for Cellulose Nanomaterial. Draft for Review, WI 3021.

[62] Canadian Standards Association, Cellulosic nanomaterials - Test methods for characterization (CSA Z5100-14), 2014.

[63] S. Alila, I. Besbes, M. R. Vilar, P. Mutjé, S. Boufi, Non-woody plants as raw materials for production of microfibrillated cellulose (MFC): A comparative study, Industrial Crops and Products, 41 (2013) 250-259.

[64] B. Puangsin, Q. Yang, T. Saito, A. Isogai, Comparative characterization of TEMPO-oxidized cellulose nanofibril films prepared from non-wood resources, International Journal of Biological Macromolecules, 59 (2013) 208-213.

[65] D.Y. Liu, X.W. Yuan, D. Bhattacharyya, A.J. Easteal, Characterisation of solution cast cellulose nanofibrereinforced poly(lactic acid), Express Polymer Letters, 4 (2010) 26-31.

[66] J. Lin, L. Yu, F. Tian, N. Zhao, X. Li, F. Bian, J.Wang, Cellulose nanofibrils aerogels generated from jute fibers, 
Carbohydrate Polymers, 109 (2014) 35-43.

[67] B. Deepa, E. Abraham, N. Cordeiro, M. Mozetic, A. P. Mathew, K. Oksman, M. Faria, S. Thomas, L.A. Pothan, Utilization of various lignocellulosic biomass for the production of nanocellulose: a comparative study, Cellulose, 22 (2015) 1075-1090.

[68] J. Lv, D. Zeng, C. Wei, Mechanical and wear properties of sisal fiber cellulose microcrystal reinforced unsaturated polyester composites, Advances in Polymer Technology, 34(2) (2015) 21483.

[69] M. F. Rosa, E. S. Medeiros, J. A. Malmonge, K. S. Gregorski, D. F. Wood, L. H. C. Mattoso, G. Glenn, W. J. Orts, S. H. Imam, Cellulose nanowhiskers from coconut husk fibers: effect of preparation conditions on their thermal and morphological behavior, Carbohydrate Polymers, 81 (2010) 83-92.

[70] Y. Habibi, L. A. Lucia, O. J. Rojas, Cellulose nanocrystals: Chemistry, self-assembly, and applications, Chemical Reviews, 110 (2010) 3479-3500.

[71] L. Berglund, in: Natural fibers, biopolymers, and biocomposites, A. K. Mohanty, M. Misra, L. T. Drzal (Eds.), CRC Press, Boca Raton, USA, 2005, p. 807.

[72] K. Spence, Y. Habibi, A. Dufresne, in: Cellulose Fibers: Bio- and Nano-Polymer Composites, S. Kalia, B.S. Kaith, I. Kaur (Eds.), Springer, Berlin, 2011, p. 179.

[73] S. Thomas, S. A. Paul, L. A. Pothan, B. Deepa, in: Cellulose Fibers: Bio- and Nano-Polymer Composites, S. Kalia, B.S. Kaith, I. Kaur (Eds.). Springer, Berlin, 2011, p. 3.

[74] V. Barbash, O. Yaschenko, in: Novel Nanomaterials, K. Krishnamoorthy (Ed.), IntechOpen, 2020, DOI: 10.5772/intechopen.94272. Available from: https://www. intechopen.com/chapters/73744

[75] M. Beaumont, A. Potthast, T. Rosenau, in: Cellulose Science and Technology: Chemistry, Analysis, and Applications, Thomas Rosenau, Antje Potthast, Johannes Hell (Eds), Wiley, 2018, p. 277.

[76] A. Dufresne, Nanocellulose: From Nature to High Performance Tailored Materials, Walter de Gruyter $\mathrm{GmbH}$, Berlin/Boston, 2012.

[77] J. Zhang, H. Kitayama, Y. Gotoh, High strength ultrafine cellulose fibers generated by solution blow spinning, European Polymer Journal, 125 (2020) 109513.

[78] M. P. Vocht, R. Beyer, P. Thomasic, A. Müller, A. Ota, F. Hermanutz, M. R. Buchmeiser, High-performance cellulosic filament fibers prepared via dry-jet wet spinning from ionic liquids, Cellulose, 28 (2021) 3055-3067.

[79] S. Wang, A. Lu, L. Zhang, Recent advances in regenerated cellulose materials, Progress in Polymer Science, 53 (2016) 169-206.

[80] J. Zhang, J. Wu, J. Yu, X. Zhang, J. He, J. Zhang, Application of ionic liquids for dissolving cellulose and fabricating cellulose-based materials: state of the art and future trends, Materials Chemistry Frontiers, 1(7) (2017) 1273-1290.

[81] J. Zhang, K. Tominaga, N. Yamagishi, Y. Gotoh, comparison of regenerated cellulose fibers spun from ionic liquid solutions with Lyocell fiber, Journal of Fiber Science and Technology, 76(8) (2020) 257-266.

[82] I. Sulaeva, U. Henniges, T. Rosenau, A. Potthast, Bacterial cellulose as a material for wound treatment: Properties and modifications. A review, Biotechnology Advances, 33(8) (2015) 1547-1571.

[83] I. Sulaeva, H. Hettegger, A. Bergen, C. Rohrer, M. Kostic,
J. Konnerth, T. Rosenau, A. Potthast, Fabrication of bacterial cellulose-based wound dressings with improved performance by impregnation with alginate, Materials Science and Engineering: C, 110 (2020) 110619.

[84] S. Bandyopadhyay-Ghosh, S. B. Ghosh, M. Sain, in: Industrial Applications of Natural Fibres: Structure, Properties and Technical Applications, J. Müssig (Ed.), Wiley, Chichester, 2010, p. 459.

[85] S. Qing, C. Wu, High performance cellulose nanofibrils composite films, BioResources, 07(3) (2012) 3064-3075.

[86] J. Miller, Nanocellulose Producers, Products, and Applications: A Guide for End Users, TAPPI, 2017.

[87] L. Berglund, in: Natural fibers, biopolymers, and biocomposites, A. K. Mohanty, M. Misra, L. T. Drzal (Eds.). CRC Press, Boca Raton, USA. 2005, p. 807.

[88] J. Huang, A. Dufresne, N. Lin (Eds.), Nanocellulose: From Fundamentals to Advanced Materials, Wiley-VCH Verlag $\mathrm{GmbH} \&$ Co. KGaA. 2019.

[89] K.-Y. Lee (Ed.), Nanocellulose and Sustainability: Production, Properties, Applications, and Case Studies, CRC Press, 2020.

[90] D. Kumar (Ed.), Nanocellulose and Its Composites for Water Treatment Applications, CRC Press, 2021.

[91] Md Rezaur Rahman (Ed., Fundamentals and Recent Advances in Nanocomposites Based on Polymers and Nanocellulose, Elsevier, 2021.

[92] D. Trache, V. K. Thakur (Eds.), Nanocellulose and Nanocarbons Based Hybrid Materials: Synthesis, Characterization and Applications, MDPI, Basel, 2020.

[93] V. K. Thakur, E. Frollini, J. Scott (Eds.), Cellulose Nanoparticles, Royal Society of Chemistry, 2021.

[94] Future Markets Inc., The Global Market For Nanocellulose 2017 to 2027, Future Markets Inc., 2017.

[95] R. P. Swatloski, S. K. Spear, J. D. Holbrey, R. D. Rogers, Dissolution of cellulose [correction of cellose] with ionic liquids, Journal of the American Chemical Society, 124(18) (2002) 4974-4975.

[96] A. Michud, M. Tanttu, S. Asaadi, Y. Ma, E. Netti, P. Kääriainen, A. Persson, A. Berntsson, M. Hummel, H. Sixta, loncell-F: ionic liquid-based cellulosic textile fibers as an alternative to viscose and Lyocell. Textile Research Journal, 86, (2016) 543-552.

[97] N. D. Wanasekara, A. Michud, C. Zhu, S. Rahatekar, H. Sixta, S. J. Eichhorn, Deformation mechanisms in ionic liquid spun cellulose fibers. Polymer, 99 (2016) 222-230 
Izvod

\section{RAZVOJ NOVIH FUNKCIONALNIH MATERIJALA NA BAZI CELULOZE}

Mirjana Kostić

Tehnološko-metalurški fakultet, Univerzitet u Beogradu, Beograd, Srbija
(PREGLEDNI RAD)

UDK 677.46:66.017

DOI $10.5937 /$ savteh2102073K
Danas, funkcionalni materijali zasnovani na obnovljivim bioresursima i ekološki prihvatljivim procesima privlače sve veću pažnju i industrijske i naučne zajednice. Celuloza, strukturni materijal svih biljaka, najrasprostranjeniji je prirodni, obnovljivi polimer koji poseduje neka izuzetna svojstva, kao što su izuzetna mehanička svojstva, hidrofilnost, biokompatibilnost i biorazgradivost. U ovom radu dat je pregled trenutnih istraživanja u oblasti celuloze usmerenih na boljem razumevanju i primeni ovog najvažnijeg bioresursa. Naglasak je stavljen na funkcionalizaciju celuloze i njenu konverziju u nove celulozne materijale visokih performansi i dizajniranih svojstava (kao što su vlakna, filmovi, membrane, kompoziti i biomedicinski materijali). Dat je pregled različitih fizičkih i hemijskih tretmana (alkalijama, oksidacionim sredstvima, acetilovanjem, ultrazvukom, plazmom, kao i mnogi drugi tretmani i njihove kombinacije) koji se koriste za modifikaciju celuloze u cilju prilagođavanja njenih svojstava za različite namene. Pored toga, jedinstvena hijerarhijska arhitektura prirodne celuloze koja se sastoji od nanofibrila i kristalita omogućava ekstrakciju nanokristala i mikro- i nanofibrilisane celuloze mehaničkim i hemijskim metodama ili njihovim kombinacijama. Ovi nanocelulozni materijali pružaju velike mogućnosti u oblasti naprednih i funkcionalnih materijala. Na kraju, razmatrana je i nova platforma za pripremu različitih materijala na bazi celuloze kroz efikasnije i ekološki prihvatljivije procese zasnovane na novorazvijenim i „zelenim“ rastvaračima celuloze.
Ključne reči: funkcionalni materijali na bazi celuloze, funkcionalizacija celuloze, nanofibrilisana celuloza, svojstva, primena 